\title{
INCIDENCE AND PROFILE OF SEVERE ANEMIA IN CHILDREN AGED 1 MONTH TO 14 YEARS ATTENDING TERTIARY LEVEL CARE HOSPITAL
}

\author{
Antony Jenifer J' ${ }^{1}$, Sai Santhosh R. B2 ${ }^{2}$ Suresh $P^{3}$ \\ ${ }^{1}$ Associate Professor, Department of Paediatrics, Chettinad Hospital and Research Institute, Chennai. \\ 2 Post Graduate, Department of Paediatrics, Chettinad Hospital and Research Institute, Chennai. \\ ${ }^{3}$ Professor, Department of Paediatrics, Chettinad Hospital and Research Institute, Chennai.
}

\begin{abstract}
AIM

To find out incidence and clinical profile of severe anaemia in children aged 1 month to 14 years attending tertiary care hos pital.

\section{METHODS}

All children aged 1 months to 14 yrs of age attending tertiary level care. It is a Prospective study with a sample size of 1370 cases.

\section{RESULTS}

Incidence of anemia in1month to 14yrs age groupis $84.2 \%$.Incidence of Severe Anemia is $4.33 \%$. Etiological diagnosis in children aged 1 month to $14 y$ rs with severe anemia is Iron Deficiency Anemia 40\%, Malaria 17\%, SickleCell Anemia 15\%, Beta Thalasemia 11\%, Septicemia 4\%, CollagenVascular Disease 4\%, Malignancies 4\%, Dimorphic Anemia 2\%,Beta Thalasemia Trait 2\%.
\end{abstract}

\section{CONCLUSIONS}

Anemia is the most common comorbid condition in children aged 1 month to 14 years, accounting for $84 \%$. Incidence of severe anemia is $4.3 \%$. Iron deficiency anemia is the most common etiological diagnosis of severe anemia.

\section{KEYWORDS}

Anaemia, Etiological Diagnosis, Incidence.

HOW TO CITE THIS ARTICLE: Antony Jenifer J, Sai Santhosh RB, Suresh P. Incidence and profile of severe anemia in children aged 1 month to 14 years attending tertiary level care hospital. J. Evolution Med. Dent. Sci. 2016;5(17):832-833,

DOI: $10.14260 /$ jemds/2016/192

\section{INTRODUCTION}

Anemia is defined as reduction in the concentration of hemoglobin in the peripheral blood which below normal for age and sex. Anaemia increases slightly from age 6-8 months to age 12-17 months, and declines steadily at older ages. Prevalence of anaemia does not vary by the sex of the child. Iron deficiency anemia is the most common cause of anemia. The prevalence of iron deficiency anemia in developing countries like India has been found to be as high as $63 \%$ in 13 year age group and $44 \%$ in the age group 3 to 6 years of children as per a study by ICMR in 1977. More recent report of the NFHS- 2 shows that the prevalence has not much changed in $1998-1999$ and is still $74 \%$ among children of $6-35$ months of age. ${ }^{1}$ this study was aimed to find out incidence and clinical profile of severe anaemia in children aged 1 month to 14 years attending tertiary care hospital.

\section{MATERIALS AND METHODS}

This study was conducted in paediatric OPD, at chettinad hospital and research institute, Chennai. All children aged between 1 month to 14 yrs of age, attending paediatric opd

Financial or Other, Competing Interest: None.

Submission 09-12-2015, Peer Review 10-02-2016,

Acceptance 16-02-2016, Published 26-02-2016.

Corresponding Author:

Dr. Suresh P,

Sri Mokkambika, Old No. 4, New No. 8/1,

Bali Avenue, Valmiki Street,

Chennai-600041.

E-mail: sureshp39@ymail.com

DOI: $10.14260 /$ jemds/2016/192 were included in the study. It is a Prospective study with a sample size of 1370 cases. Duration of Study: one year (June 2014 to may2015).

Anemia is diagnosed if $\mathrm{Hb} \%$ is below $11 \mathrm{gm} / \mathrm{dL}$ (In children aged 1 months to 6 years) and below $12 \mathrm{gm} / \mathrm{dL}$ (In children aged 6years to 12 years). Severity of Anemia is graded as: Severe (0 to $6.9 \mathrm{gm} / \mathrm{dL}$ ), Moderate ( 7 to $9.9 \mathrm{gm} / \mathrm{dL}$ ) ,Mild (10 to $12 \mathrm{gm} / \mathrm{dL}$ ). ${ }^{2,3,4}$ They were evaluated for anemia by hemoglobin estimation. Those children who were having $\mathrm{Hb}$ less than $7 \mathrm{~g} \%$ were admitted and completely evaluated to know the etiology.

\section{RESULTS}

\begin{tabular}{|c|c|c|c|}
\hline Age & Mild & Moderate & Severe \\
\hline 1 MONTH - & 216 & 285 & 22 \\
5YRS & $(41.3 \%)$ & $(54.49 \%)$ & $(4.2 \%)$ \\
\hline \multirow{2}{*}{ 6YRS - 14YRS } & 236 & 366 & 28 \\
& $(37.46 \%)$ & $(58.09 \%)$ & $(4.44 \%)$ \\
\hline \multirow{2}{*}{ TOTAL } & $\mathbf{4 5 2}$ & $\mathbf{6 5 1}$ & $\mathbf{5 0}$ \\
& $\mathbf{( 3 9 . 2 \% )}$ & $\mathbf{( 5 6 . 4 6 \% )}$ & $\mathbf{( 4 . 3 3 \% )}$ \\
\hline
\end{tabular}

Table 1: Incidence of Severity of Anemia by Age

Incidence of severity of anemia by age In 1years to 5 yrs of age children: Mild $41.3 \%$, moderate $54.49 \%$,severe anemia in $4.2 \%$.In 6yrs to $14 y$ rs of age children: Mild $37.46 \%$, moderate $58.09 \%$, severeanemia $4.44 \%$.The incidence of severe of anemia is more in 6yrs to $14 \mathrm{yrs}$. 


\begin{tabular}{|c|c|c|c|}
\hline HISTORY & TOTAL & & \\
\hline \multirow{3}{*}{ FEVER } & \multirow{3}{*}{32} & $<1$ YEAR & 04 \\
\hline & & 1 -5 YEAR & 12 \\
\hline & & 6-14 YEAR & 16 \\
\hline \multirow{3}{*}{ HOOK WORMS } & \multirow{3}{*}{22} & $<1$ YEAR & NIL \\
\hline & & 1 -5 YEAR & 01 \\
\hline & & 6- 14 YEAR & 21 \\
\hline \multirow{3}{*}{ JAUNDICE } & \multirow{3}{*}{08} & $<1$ YEAR & NIL \\
\hline & & 1 -5 YEAR & 01 \\
\hline & & 6- 14 YEAR & 07 \\
\hline \multirow{3}{*}{$\begin{array}{c}\text { BLOOD } \\
\text { TRANSFUSIONS }\end{array}$} & \multirow{3}{*}{07} & $<1$ YEAR & 02 \\
\hline & & 1 -5 YEAR & 04 \\
\hline & & 6- 14 YEAR & 01 \\
\hline \multirow{3}{*}{$\begin{array}{l}\text { SIBLINGS WITH } \\
\text { SIMILAR COMPLAINTS }\end{array}$} & \multirow{3}{*}{03} & $<1$ YEAR & NIL \\
\hline & & 1 -5 YEAR & 01 \\
\hline & & 6- 14 YEAR & 02 \\
\hline \multirow{3}{*}{$\begin{array}{l}\text { FEEDING } \\
\text { DIFFICULTIES }\end{array}$} & \multirow{3}{*}{02} & $<1$ YEAR & 02 \\
\hline & & 1 -5 YEAR & NIL \\
\hline & & 6- 14 YEAR & NIL \\
\hline \multicolumn{4}{|c|}{$\begin{array}{c}\text { Table 2: Significant History in Children with Severe } \\
\text { Anemia }\end{array}$} \\
\hline
\end{tabular}

Significant history in children with which severity of anemia presented 32 cases with fever with anaemia seen in malaria, kalaazar, tuberculosis, malignancy, hookworm infestation etc. 22 cases with hook worm infestation with history of abdominal pain,colic, intestinal cramps, nausea, fever, blood in your stool, appetite loss, itchy rash.8 cases with jaundice, 7 cases with blood transfusions, 3 siblings with similar complaints, 2 cases with feeding difficulties is GERD. Most common significant history is fever.

\begin{tabular}{|c|c|}
\hline HEPATOMEGALY & 28 \\
\hline SPLEENOMEGALY & 23 \\
\hline JAUNDICE & 13 \\
\hline EDEMA & 08 \\
\hline CLUBBING & 01 \\
\hline LYMPHADENOPATHY & 01 \\
\hline SIGNS OF TB & 01 \\
\hline SIGNS OF RENAL FAILURE & 01 \\
\hline \multicolumn{2}{|c|}{ Table 3: Positive Examination Findings } \\
in Patients with Severe Anemia \\
\hline
\end{tabular}

Positive examination findings in patients with severe anemia, 28 patients with Hepatomegaly, 23 with Spleenomegaly, 13 with Jaundice, 8 with Edema, 1 with Clubbing, 1 with Lymphadenopathy, 1 with Signs of Tb, and 1 with Signs of Renal Failure like facial puffiness, decreased urine output, and hypertension.

\begin{tabular}{|c|c|}
\hline IRON DEFICIENCY ANEMIA & $40 \%$ \\
\hline MALARIA & $17 \%$ \\
\hline SICKLE CELL ANEMIA & $15 \%$ \\
\hline BETA THALASEMIA & $11 \%$ \\
\hline SEPTICEMIA & $4 \%$ \\
\hline COLLAGEN VASCULAR DISEASE & $4 \%$ \\
\hline MALIGNANCIES & $4 \%$ \\
\hline DIMORPHIC ANEMIA & $2 \%$ \\
\hline BETA THALASEMIA TRAIT & $2 \%$ \\
\hline \multicolumn{2}{|c|}{ Table 4: Etiological Diagnosis in Children } \\
with Severe Anemia
\end{tabular}

Etiological diagnosis in children with severe anaemia. Iron Deficiency Anaemia 40\%, Malaria 17\%, Sickle Cell Anaemia 15\%, Beta Thalasemia 11\%, Septicemia 4\%, Collagen Vascular Disease 4\%, Malignancies include ALL, AML 4\%, Dimorphic Anaemia 2\%, Beta Thalasemia Trait2\%.

\section{DISCUSSION}

This study shows that anaemia is major health problem in children. Incidence of anaemia in the present study is $84 \%$. In $1 \mathrm{month}$ to $5 y \mathrm{rs} 78.05 \%$ are anaemic, in 6yrs to $14 \mathrm{yrs} 90 \%$ are anaemic. In the age group of 6yrs to $14 y$ rs anaemia incidence is more than in 1month to 5yrs. In our study the incidence of severity of anaemia in 6years to 14years is mild $37.46 \%$, moderate $58.49 \%$, severe $4.44 \%$. when compared to a study in tribal area of childhood anaemia in Mohana block in Orissa 5yrs to 14 yrs by T sahu, N C Sahani , L Patnaik showed almost all children (99\%) were found to be anaemic, more than $60 \%$ of them had moderate to severe anaemia. ${ }^{5}$ In their study they found mild, moderate, severe anaemia to be $42.1 \%, 49.1 \%$, $8.8 \%$ respectively.

Verma M. etal in their study on urban school children of age group 5 -15years in Punjab found prevelance of anaemia was $51.5 \%{ }^{6}$ Verma A .etal in their study on adolescent girls found mild , moderate, severe anaemia to be $36.6 \%$, $22.4 \%$, $4.8 \%$ respectively. ${ }^{7}$ In our study Iron Deciency anemia is the most common diagnosis, followed by malaria, Sickle Cell Anemia, Beta Thalasemia, Septicemia which is compared to a study by Gomber, Sunil et al found iron deficiency anaemia was the commonest type of anaemia noted in 68.42 per cent( 65 of 95) children. ${ }^{8}$

\section{CONCLUSIONS}

Anemia is the most common comorbid condition in children aged 1 month to 14 years, accounting for $84 \%$. Incidence of severe anemia is $4.3 \%$. Iron deficiency anemia is the most common etiological diagnosis of severe anemia. Incidence of anemia and severe anemia is more in 6years to 14years. Incidence of anemia is more in males than in females, but severe anemia is more common in females than in males. Most common physical findings in patients presented with severe anemia is hepatospleenomegaly. Most common etiological diagnosis in all age groups is iron deficiency anemia. But beta thalasemia, sickle cell anemia, malaria are not less important.

\section{BIBLIOGRAPHY}

1. National Family Health Survey 1992-99 [Analysis in brief on internet] [cited: 2016 Feb 22]. Available from https://nfhsindia.org/data/india/indch 7.pdf.

2. UNICEF. State of the world's children report; 1997 [cited 2016 Feb 20]. Available from http://www.Unicef.org/sowc97/download/sow10f2.pdf.

3. Parthasarathy A, Menon, Piyush Gupta, et al. IAP Textbook of paediatrics. 5th edition. New Delhi; Jaypee Brothers; c2013. p 638-42.

4. Kenneth R, Howard. Anaemias and other red cell diseases. 8th edition. New York; McGraw Hill; c2008.

5. Sahu T, Sahani NC, Patnaik L. Iron deficiency in India. Recent advances in paediatrics special volume in haematology. Eds. Gupte Suraj. Published By Jaypee 2000;7:1-21.

6. Verma M, Chhatwal J, Gurumeet Kaur. Prevalence of anaemia among urban school children of Punjab. Indian paediatrics 1998;35(12):1181-1188.

7. Verma A, Rawal VS, Kedia G, et al. Factors influencing anaemia among girls of school going age (6-18 yrs.) from the slums of Ahmedabad city. Indian Journal of Community Medicine Jan-Mar 2004;29(1):25-26.

8. Sunil Gomber, Bhawna, Nishi Madan, et al. Prevalence and etiology of nutritional anaemia among school children of urban slums. Indian Journal of Medical Research 118 (Oct 2003):167-171. 